\title{
PEMBERDAYAAN MASYARAKAT DALAM PENGELOLAAN POTENSI DESA DI BIDANG PERTANIAN, PETERNAKAN DAN HOME INDUSTRY MENUJU DAERAH WISATA MANDIRI
}

\author{
I.P.A. Astawa ${ }^{1}$, I.K.A. Atmika ${ }^{2}$, I.A.A.A.S. Komaladewi ${ }^{3}$
}

\begin{abstract}
ABSTRAK
Desa Batur Tengah termasuk dalam wilayah Kecamatan Kintaman dengan jumlah penduduk kurang lebih 4250 jiwa atau 850 kepala keluarga (KK). Desa ini terdiri dari 8 banjar/dusun. Mata pencaharian sebagian besar penduduk adalah dari sektor pertanian, dan beberapa bergerak di sektor agrobisnis. Lahan pertanian dan perkebunan mereka banyak ditanami padi, jeruk dan kopi dimana tersebar sepanjang wilayah/daerah di Desa Batur Tengah. Potensi yang masih perlu digali yakni bidang perkebunan jeruk dan home industri. Selain itu, perkebunan jeruk yang tersebar hampir di seluruh wilayah desa Batur Tengah hanya difokuskan sebagai sumber produksi buah, nantinya diharapkan dapat dikembangkan menjadi objek wisata buah seperti kebanyakan tempat agrowisata lainnya. Kegiatan KKN PPM di Desa Batur Tengah bertujuan memberdayakan masyarakat dalam menggali potensi alam dan SDM yang dimiliki: 1)Pemberdayaan dan meningkatkan pengetahuan industri kecil bagaimana meningkatkan produktifitas dan diversifikasi produk, 2)Pemberdayaan dan meningkatkan pengetahuan anggota kelompok ternak tentang kemungkinan pemanfaatan jerami padi sebagai sumber pakan ternak sapi, 3)Pemberdayaan kelompok peternak melalui peningkatan pengetahuan dan keterampilan mengenai cara pembuatan pupuk organik dari kotoran ternak sapi dan proses pemanfaatannya sebagai biogas, 4)Memberikan pengetahuan dan ketrampilan pengelolaan lahan dan pemasaran hasil produksi terutama produksi jeruk menuju kearah agrowisata. Pelaksanaan kegiatan dibagi menjadi tiga tahapan. Tahapan pertama adalah persiapan dan pembekalan, tahap kedua implementasi/pelaksanaan kegiatan di lapangan, dan tahap ketiga evaluasi dan monitoring untuk koreksi dan penyempurnaan keberlanjutan program. Tahap persiapan dimulai audensi dengan aparat desa dan tokoh masyarakat untuk menentukan skala prioritas kegiatan berdasarkan kondisi dan potensi yang ada di masyarakat. Tahap pelaksanaan kegiatan dilakukan dengan penyuluhan maupun praktek di lapangan, maupun pendampingan oleh mahasiswa peserta KKN selama di lapangan. Sedangkan tahap ketiga adalah evaluasi dan monitoring dilakukan oleh tim pelaksana/dosen pembimbing lapangan dan koordinator KKN untuk melihat dampak dan keberlanjutan program yang sudah dilaksanakan.
\end{abstract}

Kata kunci : Jerami, biogas, home industri, pupuk organik, agrowisata.

\begin{abstract}
Batur Tengah village was included in the District of Kintaman with a population of approximately 4250 people or $850 \mathrm{KK}$. The village consists of eight banjar. Livelihood of the majority of the population is in agriculture, and some engaged in the agribusiness sector. Agricultural land and many of their estates planted with rice, oranges and coffee which are scattered throughout the regions in Batur Tengah village. The potential that still need to be explored the field of citrus plantations and home industry. In addition, citrus groves spread almost the entire territory of Batur Tengah village just focused as a source of fruit production, is expected to be developed into a tourist attraction agro fruit like most other places. KKN PPM in Batur Tengah village aimed at empowering the community to explore the potential of natural and human resources:
\end{abstract}

\footnotetext{
${ }^{1}$ Staf Pengajar Jurusan Peternakan Fakultas Peternakan Universitas Udayana, iptariastawa@yahoo.co.id

${ }^{2}$ Staf Pengajar Jurusan Teknik Mesin Fakultas Teknik Universitas Udayana

${ }^{3}$ Staf Pengajar Jurusan Teknik Mesin Fakultas Teknik Universitas Udayana
} 
1) Empowerment and increase industry knowledge how to improve productivity and product diversification,

2) Empowerment and increase the knowledge of members of the cattle on the possibility of utilization of rice straw as a source cattle feed, 3) Empowerment of groups of farmers through increased knowledge and skills on how to manufacture organic fertilizer from cattle dung and process utilization as biogas, 4) Provide the knowledge and skills of land management and marketing of the production, especially the production of citrus heading towards agritourism. Implementation activities are divided into three stages. The first stage is the preparation and debriefing, the second phase of implementation of activities in the field, and the third stage of evaluation and monitoring for correction and improvement of the sustainability of the program. The preparation phase begins hearings with village officials and community leaders to determine the scale of priority actions based on the conditions and the potential that exists in society. Stages of implementation of the activities carried out by counseling and practice in the field, as well as mentoring by students participating in service learning while in the field. While the third stage is the evaluation and monitoring are done by the implementation team and coordinator to see the impact and sustainability of programs.

Keywords : straw, biogas, home industry, organic fertilizer, agro-tourism.

\section{PENDAHULUAN}

Desa Batur Tengah adalah salah satu desa yang ada di kecamatan Kintamani kabupaten Bangli, dengan wilayah seluas 1260 are, terletak pada ketinggian 400-700 meter di atas permukaan laut. Jumlah penduduk desa Batur Tengah kurang lebih 4250 jiwa atau 850 kepala keluarga (BPS Kabupaten Bangli, 2012). Secara geografis Desa Batur Tengah merupakan bagian dari kawasan Munduk Gunung Batur, dataran tinggi yang membujur dari Utara ke Selatan. Wilayah bagian timur berbatasan dengan Danau Batur dan desa Kedisan, di bagian utara berbatasan dengan gunung Batur dan desa Batur Utara, sebelah selatan berbatasan dengan Desa Bayung Gede, dan di sebelah barat berbatasan dengan desa Batur Selatan. Desa Batur Tengah merupakan bagian dari desa pekraman Batur yang membawahi 24 banjar dinas, sedangkan desa Batur Tengah sendiri terdiri dari 8 banjar/dusun, yaitu banjar Batur Tengah, banjar Petung, banjar Telembah, banjar Bugbugan, banjar Tandang, banjar Batur Kota, banjar Bubung Kelambu, dan banjar Toya Bungkah.

Mata pencaharian sebagian besar penduduk adalah dari sektor pertanian, dan beberapa bergerak di sektor agrobisnis. Lahan pertanian dan perkebunan mereka banyak ditanami padi, jeruk dan kopi dimana tersebar sepanjang wilayah/daerah di Desa Batur Tengah. Pertanian di desa ini terorganisir dalam lembaga pertanian tradisional yang disebut subak. Organisasi subak di Desa Batur Tengah terbagi menjadi dua yaitu 10 Subak Kering, dan 8 Subak Air. Petani padi banyak terkonsentasi di banjar Toya Bungkah yang memanfaatkan air danau batur sebagai sumber irigasi subak. Disamping berkebun masyarakat memanfaatkan lahannya untuk beternak sapi, babi, dan juga ayam kampung.

Potensi yang masih perlu digali yakni bidang perkebunan jeruk dan home industri. Perkembangan potensi-potensi di bidang tersebut selain akan menjadi daya tarik wisata, juga sebagai penunjang perkembangan industri rumah tangga yang akan bersinergi dengan upaya peningkatan kesejahteraan masyarakat setempat. Selain itu, perkebunan jeruk yang tersebar hampir di seluruh wilayah desa Batur Tengah hanya difokuskan sebagai sumber produksi buah, nantinya diharapkan dapat dikembangkan menjadi objek wisata buah seperti kebanyakan tempat agrowisata lainnya.

Sumber daya wisata lain di desa Batur Tengah yang memiliki potensi wisata tinggi namun belum digali misalnya dengan pengolahan jerami yang ada digunakan sebagai pakan ternak dan juga pemanfaatan kotoran hewan dijadikan pupuk kompos. Prospek dan potensi pemanfaatan kotoran ternak di desa Batur Tengah ini sangat bagus karena 3 kelompok tani/ternak yang sedang berkembang, yaitu gapoktan Dana Kembang Lestari, gapoktan Karya Sejahtera, gapoktan Guna Winangun. Dalam upaya menanggulangi limbah di atas maka di rancanglah program pengolahan jerami yang ada digunakan sebagai pakan ternak, pengolahan limbah kotoran ternak sapi menjadi pupuk organik (kompos) serta pembuatan biogas.

\section{2 | BULETIN UDAYANA MENGABDI}


Di bagian selatan desa Batur Tengah tepatnya Banjar Bugbugan terdapat pula kelompok usaha "UD. Mekar Sari" yang sementara produk utamanya adalah mengolah hasil pertanian kacang tanah menjadi kacang asin. UD Mekar Sari berdiri di atas tanah seluas $100 \mathrm{~m} 2$ dengan luas bangunan $4 \mathrm{x}$ $6 \mathrm{~m} 2$. Kelompok Usaha ini mempunyai potensi yang sangat bagus, tetapi belum bisa berkembang dikarenakan peralatan dan manajemen masih sederhana. Kurang berkembangnya UD Mekar Sari disebabkan oleh masih terbatasnya mesin sangrai/alat penggulingan atau kapasitas produksi alat/mesin masih kecil.

Kesempatan kerja untuk lulusan perguruan tinggi di wilayah ini banyak yang tidak terserap di pasar kerja pariwisata yang berkembang di Desa Batur Tengah. Sementara itu potensi yang ada hampir di seluruh wilayah seperti perkebunan, peternakan dan industri kecil kacang asin cukup menjanjikan sebagai sumber pendapatan masyarakat desa. Pemberdayaan masyarakat sangat diperlukan baik dalam penguasaan teknologi, kemampuan manajemen, wawasan kewirausahaan, maupun kemampuan dalam membangun jaringan kemitraan (Sumodiningrat, et.all.1997, Hikmat, et.all. 2001, dan Purba, et.all. 2008).

Pengembangan potensi wisata Desa Batur Tengah tentu harus didukung dari berbagai aspek, baik dari aspek sumber daya wisata maupun sumber daya manusia yang akan mengelola potensi wisata selanjutnya. Dengan banyaknya potensi yang dapat dikembangkan, langkah awal yang dapat dilakukan adalah dengan meningkatkan sumber daya manusia.

Tujuan kegiatan KKN PPM di Desa Batur Tengah adalah memberdayakan masyarakat dalam menggali potensi yang dimiliki di wilayahnya. Untuk mencapai tujuan tersebut dapat dijabarkan dalam bentuk yang spesifik sebagai berikut:

- Pemberdayaan dan meningkatkan pengetahuan anggota kelompok ternak tentang kemungkinan pemanfaatan jerami padi sebagai sumber pakan ternak sapi.

- Pemberdayaan kelompok Petani jeruk melalui peningkatan pengetahuan dalam meningkatkan produksi dan kualitas jeruk serta meningkatkan pengetahuan koperasi dan jiwa kewirausahaan.

- Pemberdayaan kelompok Peternak yang ada di desa Batur Tengah melalui peningkatan pengetahuan dan keterampilan mengenai cara pembuatan pupuk organik dari pemanfaatan kotoran ternak sapi dan proses pemanfaatannya sebagai biogas.

- Pemberdayaan industri keci Mekar Sari yang ada di desa Batur Tengah melalui peningkatan pengetahuan manajemen "perusahaan" yang modern sehingga meningkatkan produktifitas dan diversifikasi produk.

- Memotivasi cara dan perilaku hidup bersih dan sehat, serta menumbuhkan jiwa yang kuat untuk maju dengan meningkatkan kualitas bahasa asing dan pengetahuan IT.

\section{METODE PEMECAHAN MASALAH}

\subsection{Persiapan dan Pembekalan}

Kegiatan persiapan dan pembekalan merupakan hal penting didalam merencanakan segala sesuatunya. Pada tahap ini dosen pembimbing beserta beberapa perwakilan mahasiswa melakukan audensi kepada aparat desa serta melakukan pertemuan langsung dengan pengurus kelompok Mitra "Mekar Sari" dan tiga kelompok tani/ternak yang ada, serta masyarakat di Desa Batur Tengah. Tujuan dari pertemuan ini adalah saling bertukar pengalaman dengan harapan teridentifikasilah permasalahan-permasalahan yang ada dimasyarakat. Selanjutnya menentukan skala prioritas yang nantinya akan menjadi rencana kerja dan program selama kegiatan KKN PPM. Setelah menyusun rencana kerja/program, maka dilakukanlah pembekalan kepada mahasiswa peserta KKN PPM yang nantinya mereka akan menjadi penggerak dan ujung tombak dilapangan. Pada pembekalan ini akan dilibatkan dosen-dosen maupun praktisi yang ahli dibidang masing-masing yang akan menunjang 
program-program yang tertuang dalam rencana kerja terlaksana dengan baik.

\subsection{Pelaksanaan}

Berikutnya adalah tahapan implementasi atau pelaksanaan program di lapangan. Pada tahapan ini diimplementasikan rencana kegiatan yang telah di susun berdasarkan skala prioritas permasalahan yang ada di lapangan. Tahap pelaksanaan pada minggu kedua bulan juli sampai akhir Agustus 2017. Tahap pelaksanaan meliputi pelaksanaan penyuluhan, pelaksanaan kegiatan pendukung dan evaluasi kegiatan dengan cara wawancara langsung kepada peserta dan perangkat desa yang ikut serta dalam kegiatan ini.

Langkah - langkah operasional dalam kegiatan ini adalah sebagai berikut ;

- Penyuluhan dan praktek pengolahan jerami dengan menggunakan teknologi Biochast menjadi pakan ternak (Soebarinoto, 1997) dan penyuluhan dan praktek pemanfaatan kotoran hewan ternak untuk pupuk organik dengan teknologi Rumino Bacillus (Astawa, et.all, 2013).

- Praktek pemanfaatan kotoran hewan ternak untuk bahan bakar biogas (Fahri, 2009 dan Sunaryo, 2014).

- Penyuluhan mengenai prospek dan pentingnya manajemen serta keselamatan kerja di industri kecil (Budiono,2002). Kegiatan ini dilaksanakan pada kelompok mitra Mekar Sari yang berlokasi di banjar Bugbugan desa Batur Tengah kecamatan Kintamani Bangli.

- Penyuluhan tentang sanitasi, perilaku hidup bersih dan sehat. Kegiatan ini diarahkan menuju desa yang besih untuk menunjang desa wisata mandiri. Program ini dilanjutkan dengan pengadaan tong sampah.

- Sosialisasi Teknologi Informasi Komputer pada siswa SD Negeri 2 Batur dan SD Negeri 7 Batur di kecamatan Kintamani-Banglidan pelatihan bahasa asing bagi anak-anak dan anggota Karang Taruna, khususnya untuk menunjang pariwisata mandiri.

\section{HASIL DAN PELAKSANAAN KEGIATAN}

\subsection{Perhitungan, Perancangan Teknis, dan Manufaktur Mesin Sangrai}

Perhitungan dan perancangan sudah mulai dilaksanakan pada awal Mei 2017, lebih banyak dikerjakan di laboratorium komputer jurusan Teknik Mesin Universitas Udayana. Proses ini sudah selesai pada awal Juni 2017. Berikut adalah data perencanaan alat penyangrai kacang asin antara lain :

- Kapasitas kacang yang akan disangrai $=20 \mathrm{~kg}$

- Massa komponen tabung penyangrai $= \pm 15 \mathrm{~kg}$

- Diameter tabung $=500 \mathrm{~mm}$

- Putaran poros tabung yang diperlukan $= \pm 30 \mathrm{rpm}$

- Diameter Puli 1 (motor) $=50 \mathrm{~mm}$

- Diameter Puli 2 (transfer) $=300 \mathrm{~mm}$

- Diameter Puli 3 (transfer) $=50 \mathrm{~mm}$

- Diameter Puli 4 (tabung) $=400 \mathrm{~mm}$

Kegiatan manufaktur dan uji coba mesin dilaksanakan pada minggu ketiga bulan Juni 2017 sampai dengan awal Juli 2017 bertempat di laboratorium Produksi jurusan Teknik Mesin Universitas Udayana.

\section{4 | BULETIN UDAYANA MENGABDI}




\subsection{Kegiatan KKN PPM di lokasi/desa}

KKN PPM ini dilaksananakan selama satu bulan, yakni berlangsung dari tanggal 24 Juli $2017-28$ Agustus 2017. Tim KKN-PPM UNUD 2017 yang terlibat dalam pelaksanaan program ini sebanyak 30 orang. Pembagian pelaksanaan bidang kegiatan disesuaikan dengan disiplin ilmu dan alokasi waktu yang dimiliki masing-masing mahasiswa.

\subsection{Realisasi dan Hasil Kegiatan}

Penyuluhan dan Praktek Pengolahan Jerami dengan Menggunakan Teknologi Biochast Menjadi Pakan Ternak dan Pemanfaatan Kotoran Hewan Ternak Untuk Pupuk Organik Dengan Teknologi Rumino Bacillus

Kegiatan ini dilaksanakan dilaksanakan pada tanggal 18 Agustus 2017 yang bertempat di Balai Pertemuan Desa Batur Tengah. Kegiatan ini berjalan dengan baik yang dihadiri oleh anggota ternak Desa Batur Tengah sekitar kurang lebih 25 orang. Para warga sangat antusias dalam mengikuti penyuluhan ini. Banyak warga yang melakukan tanya jawab dengan pembicara. Melihat hal tersebut banyak hal yang dapat warga pelajari.

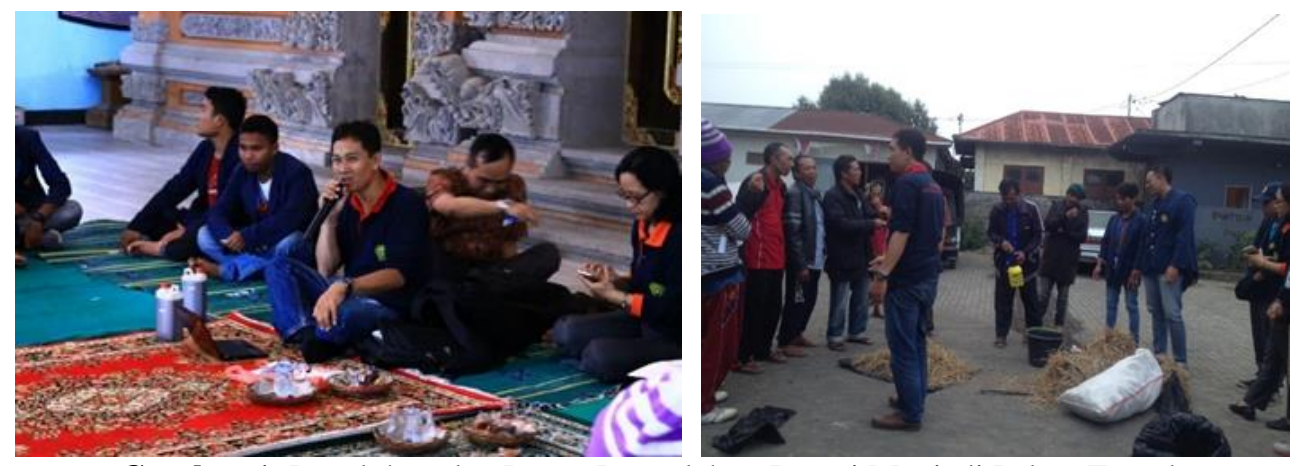

Gambar 1. Peyuluhan dan Demo Pengolahan Jerami Menjadi Pakan Ternak

Penyuluhan Dan Praktek Pemanfaatan Kotoran Hewan Ternak Untuk Bahan Bakar Biogas

Penyuluhan dan Praktek Biogas dilaksanakan pada hari tanggal 28 Juli 2017 yang bertempat di banjar Bugbugan Desa Batur Tengah. Dimana penyuluhan ini di mulai pukul. 09.00 pagi sampai dengan pukul.13.00. Pelaksanaan kegiatan ini berjalan dengan baik yang dihadiri oleh kurang lebih 25 orang anggota kelompok ternak Banjar Bugbugan dan perwakilan anggota gapoktan yang ada di desa Batur Tengah. Para peserta sangat antusias dalam mengikuti penyuluhan ini. Banyak peserta yang melakukan tanya jawab dengan pembicara. Melihat hal tersebut banyak hal yang dapat mereka pelajari. Hasil penyuluhan dan praktek pengolahan Biogas sangat memuaskan dan antusias para warga/gapoktan sangat tinggi dan penyuluhan ini memberikan pengetahuan yang sangat bermanfaat bagi bagi para peternak di Banjar Bugbugan Desa Batur Tengah. 


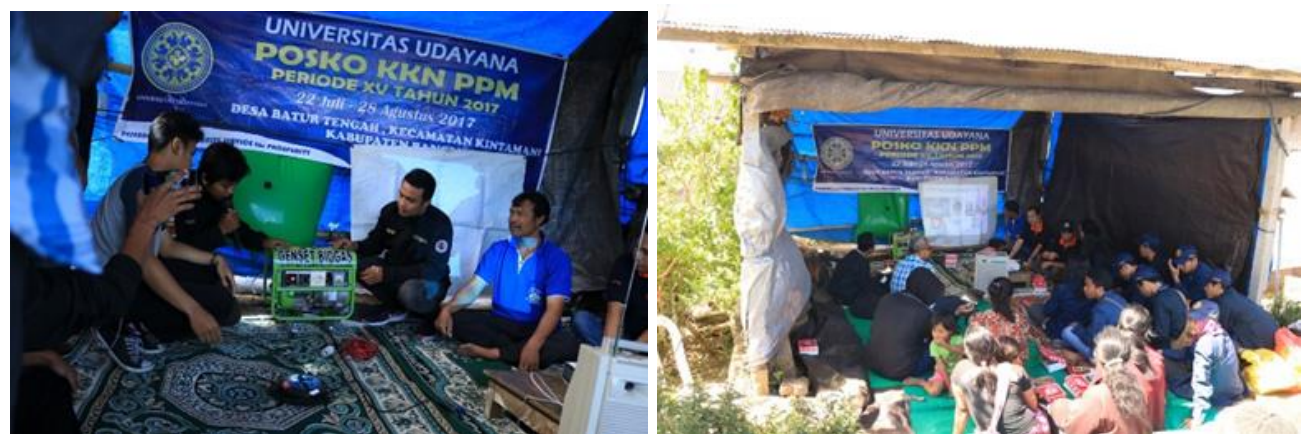

Gambar 2. Peyuluhan Dan Demo Pengoptimalan Biogas Dari Kotoran Ternak

Pemberian Pelajaran Bahasa Inggris dan Bahasa Jepang

Pelaksanaan kegiatan pelajaran Bahasa Jepang dan bahasa Inggris berlangsung ramai dan antusias anak-anak yang mengikuti kelas Bahasa jepang sangat bersemangat. Hal itu terjadi karena anakanak peserta belum pernah mendapat pelatihan Bahasa Asing di sekolahnya ataupun les private. Kegiatan ini dilaksanakan beberapa kali dari bulan Juli 2017 sd Agustus 2017.
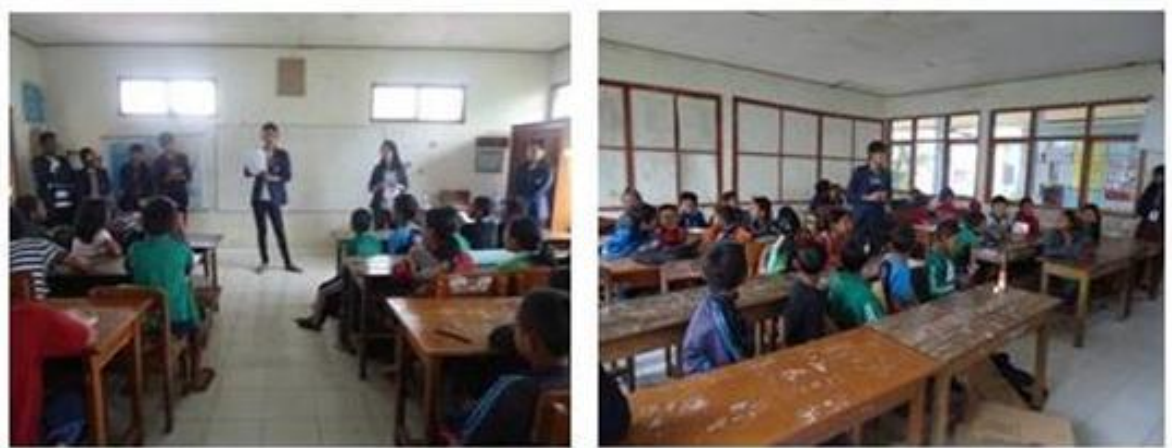

Gambar 3. Pemberian Pelajaran Bahasa Inggris dan Bahasa Jepang

Hasil kegiatan pemberian kelas pelatihan Bahasa Inggris dan Jepang menunjukkan antusiasme anak-anak yang ditunjukkan dari banyaknya peserta yang datang sehingga ruangan kelas penuh. Umpan balik yang diberikan siswa sangat aktif dan bersemangat dalam mengikuti setiap rincian kegiatan pelatihan Bahasa Inggris dan Jepang.

Pendidikan Dasar Koperasi dan Motivasi Jiwa Kewirausahaan Masyarakat Desa

Penyuluhan koperasi dan motivasi untuk berwiraswasta dilaksanakan pada tanggal 9 Agustus 2017 Bertempat di Balai Subak Banjar Petung, dimana kegiatan tersebut dimulai sekitar pukul 20.00 yang dihadiri oleh masyarakat Banjar Petung yang terdiri dari kepala keluarga, ibu-ibu PKK dan pemuda pemudi masyarakat setempat. Dalam kegiatan tersebut masyarakt Banjar Petung begitu antusias hal tersebut terlihat dengan banyaknya masyarakat yang hadir yaitu sebanyak 64 orang. 

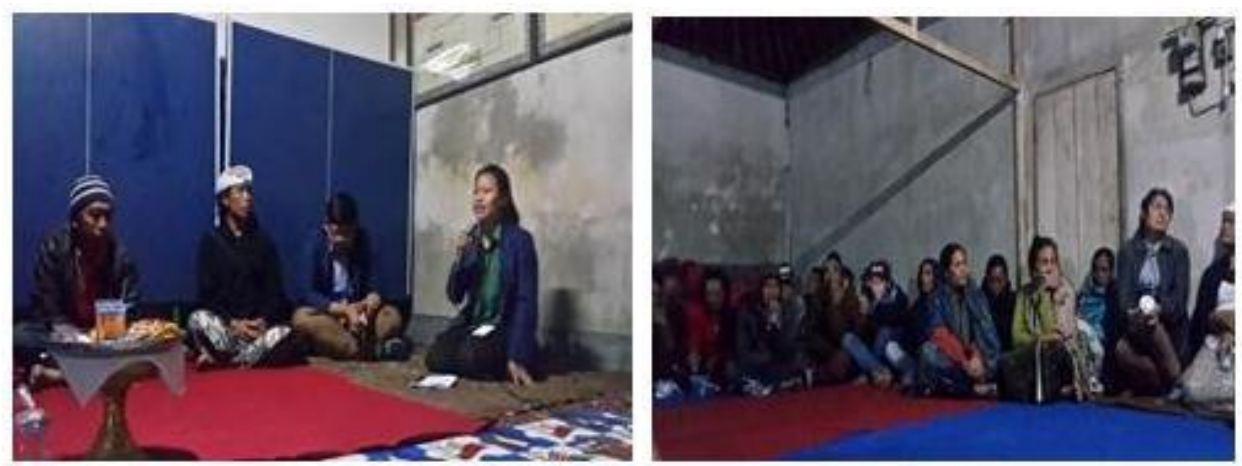

Gambar 4. Peyuluhan Koperasi dan Motivasi Jiwa Kewirausahaan

\section{$>$ Penyuluhan Keselamatan Kerja dan Manajemen Usaha Kecil}

Penyuluhan ini untuk memberikan pemahaman tentang keselamatan kerja terutama dikaitkan dengan pengoperasian mesin sangrai kacang asin, yang dilanjutkan dengan penyuluhan manajemen usaha kecil. Kegiatan ini dilaksanakan tanggal 14 Agustus 2017 bertempat di kelompok usaha Mekar Sari banjar Bugbugan.
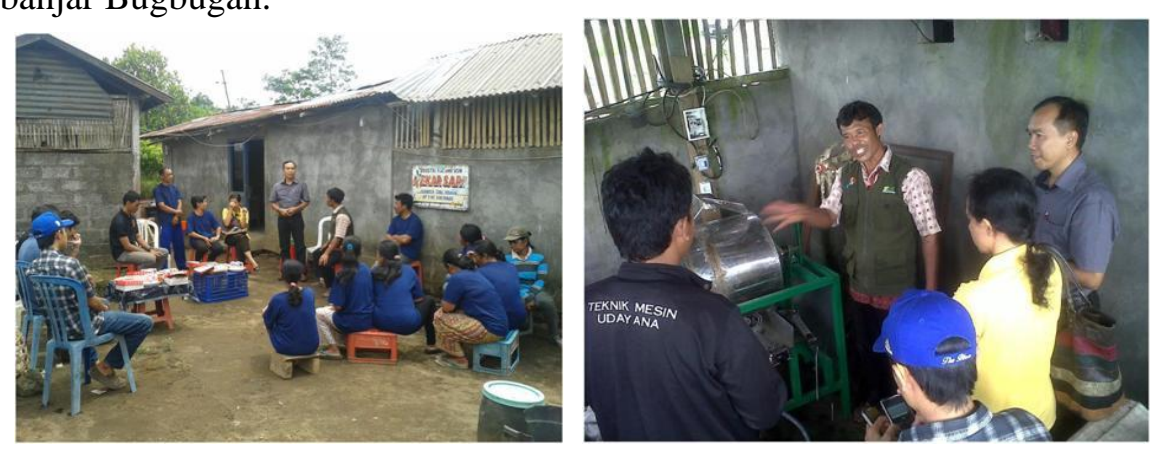

Gambar 5. Peyuluhan Keselamatan Kerja dan Manajemen Usaha Kecil

$>$ Pengembangan Objek Wisata Museum Batur Global Geopark Melalui Program Bersih-Bersih di Jalur Tracking

Pelaksanaan program ini dilakukan di museum Batur Global Geopark, Banjar Batur Tengah, Desa Batur Tengah, Kecamatan Kintamani, Kabupaten Bangli pada tanggal 07 Agustus 2017. Kegiatan ini dimulai dari jam 09:00 - 14:00 WITA. Bersih-bersih ini dilakukan mulai dari titik awal sampai titik akhir jalur tracking. Selain mahasiswa KKN-PPM, beberapa petugas dari pihak museum juga turut berpartisipasi dalam kegiatan ini. Hasil yang diperoleh dari kegiatan ini adalah jalur tracking yang dulunya penuh dengan sampah dedaunan dan plastik kini sudah bersih dan lebih baik dari sebelumnya. Kebersihan dari jalur tracking tersebut diharapkan mampu membantu berkembangnya museum Batur Global Geopark sebagai salah satu destinasi wisata di Desa Batur Tengah, Kecamatan Kintamani, Kabupaten Bangli, Bali kearah yang lebih baik.

\section{Sosialisasi dan Pembinaan Pengunaan Komputer}

Keseluruhan kegiatan pengenalan komputer ini berlangsung dengan lancar dan didukung dengan semangat belajar para siswa yang tinggi. Kegiatan ini juga dibarengi dengan kegiatan pelatihan bahasa sehingga kedua program ini dapat berjalan secara sinergis. Hasil yang didapatkan dari pelaksanaan program ini adalah para peserta sudah mengenal dasar-dasar komputer. Meski belum terlalu terampil, namun peserta nampak antusias saat mempraktikan mengetik dengan komputer. Diharapkan kegiatan ini dapat bermanfaat untuk para peserta sebagai bekal mereka saat memasuki jenjang SMP nantinya. 

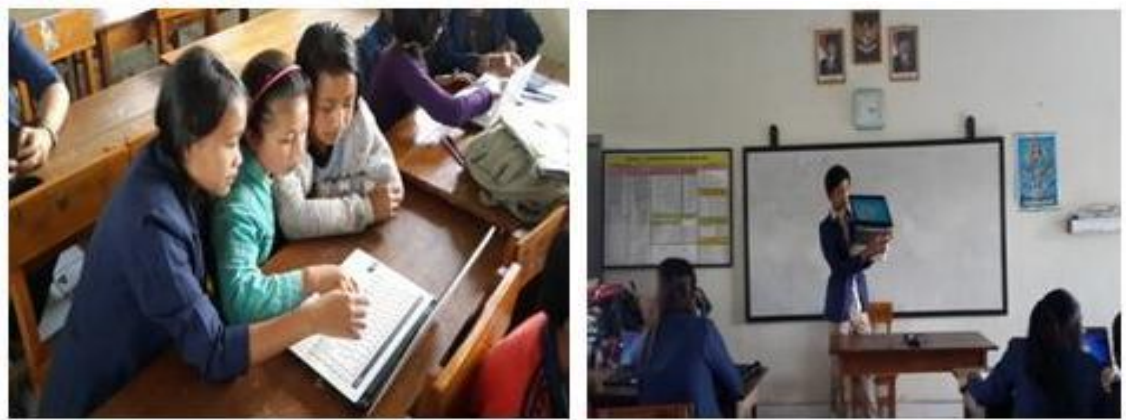

Gambar 6. Pelatihan Komputer di SDN 2 dan SDN 7 Batur

$>$ Program Penyuluhan dan Praktik Pengolahan Pasca Panen Buah Jeruk

Kegiatan utama program ini adalah pemberdayaan masyarakat guna mampu mengolah buahbuahan jeruk menjadi selai jeruk.Untuk mewujudkan hal tersebut,maka dilanjutkan dengan melakukan penyuluhan serta praktik pembuatan selai bersama-sama dengan warga.
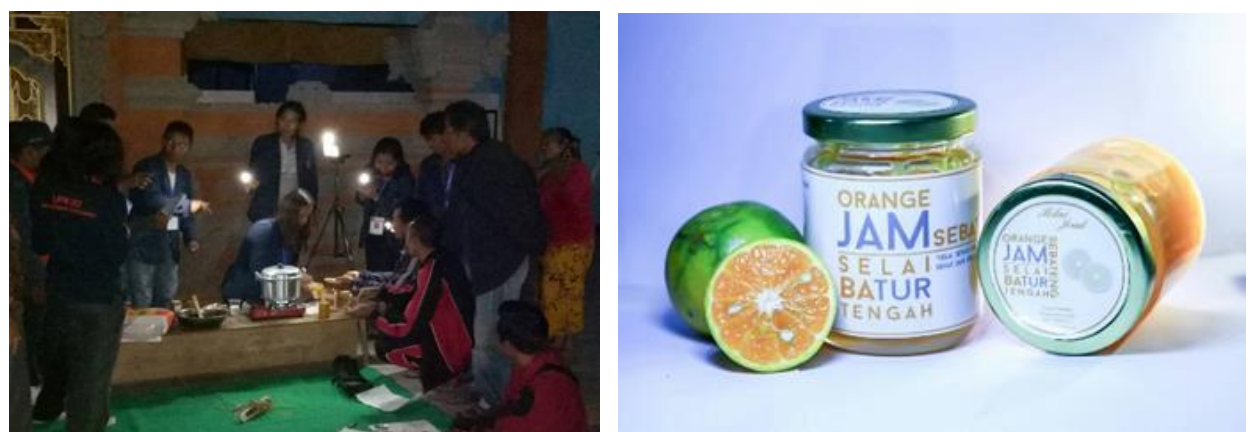

Gambar 7. Penyuluhan dan Praktik Pengolahan Pasca Panen Buah Jeruk

$>$ Penyuluhan Perilaku Hidup Bersih dan Sehat

Kegiatan diawali dengan senam pagi bersama dengan beberapa mahasiswa sebagai instruktur senam. Setelah itu, para peserta diberikan makanan sehat berupa susu dan mulai masuk ruangan tempat dilakukan penyuluhan. Khusus untuk penyuluhan mencuci tangan dan menggosok gigi, dilakukan kegiatan simulasi kepada para peserta. Melalui materi makanan dan jajanan sehat, para siswa dapat mengetahui jenis-jenis makanan yang bergizi, komposisi makanan yang benar serta makanan atau jajanan yang harus dihindari.
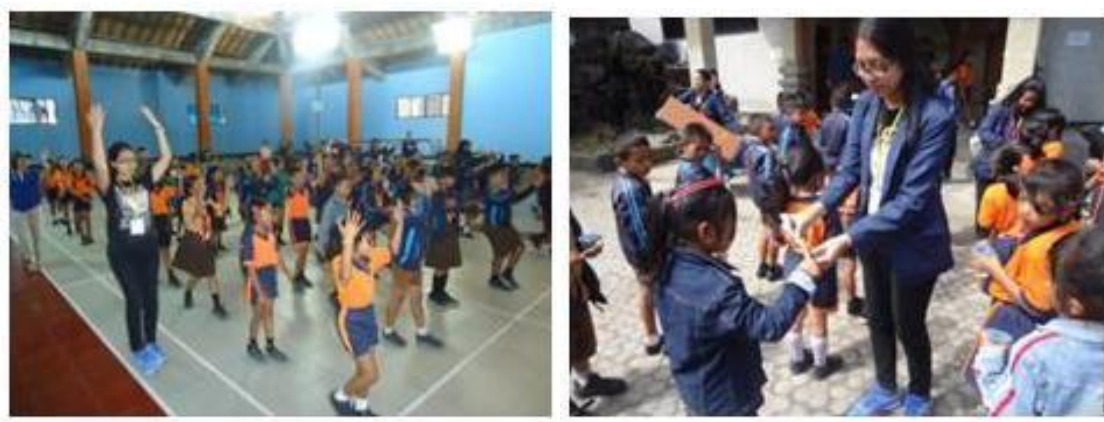

Gambar 8. Penyuluhan PHBS 


\section{SIMPULAN DAN SARAN}

Beberapa poin kesimpulan ditarik dari kegiatan pengabdian yang sudah dilaksanakan :

- Tim telah berhasil merancang mesin yang dapat membantu pengusaha kacang asin dalam meningkatkan hasil produksi. Dimana dari hasil analisa tersebut terdapat peningkatan produksi hampir 5 kali lipat.

- Pelatihan ini dapat meningkatkan ketrampilan tenaga kerja dalam memproduksi kacang asin.

- Antusiasme masyarkat untuk semua kegiatan penyuluhan dan praktek sangat tinggi.

- Melalui pengabdian ini terdapat tukar informasi antara tim sebagai akademisi di kampus dengan masyarakat, aparatur desa/banjar, dan para pengusaha pengusaha kecil di desa dalam meningkatkan potensi mereka.

Adapun beberapa hal yang disarankan adalah:

- Berdasarkan fakta dilapangan, hendaknya masing-masing anggota memiliki tugas yang pasti karena selama ini pengerjaan dilakukan berdasarkan kehadiran anggota sehingga tugasnya jadi tidak teratur.

- Pelaksanaan Pengabdian Masyarakat mendatang hendaknya perlu terus ditingkatkan, terutama dalam pembiayaan agar dapat benar-benar dapat membuat sesuatu yang baik.

\section{UCAPAN TERIMAKASIH}

Artikel ini disusun dari laporan kegiatan hibah KKN PPM yang didanai dari RisetDikti tahun 2017. Untuk itu penulis menyampaikan terima kasih yang sebesar-besarnya atas dukungan dana kegiatan pengabdian ini. Terima kasih juga disampaikan kepada LPPM Universitas Udayana yang mendukung dan memfasilitasi kegiatan penelitian dan pengabdian masyarakat untuk semua skema hibah.

\section{DAFTAR PUSTAKA}

Astawa P.A, Mahardika Gede, Budaarsa K., Budiasa K.M. 2013. Sosialisasi Pengolahan Pakan Dan Kotoran Ternak Dengan Teknologi Biofermentasi. Udayana Mengabdi 12 (2): 47 - 50.

Budiono Bambang. 2002. Industri Kecil dalam Perspektif Budaya. Surabaya. Seminar Prospek Industri Kecil Dalam Perkembangan Indonesia.

BPS Kabupaten Bangli (2012). Kintamani Dalam Angka 2012. http://banglikab.bps.go.id/publikasi/2012/kecamatan_kintamani_dalam_angka_2012/.Tanggal Akses 03 April 2014.

Fahri Anis. 2009. Teknologi Pembuatan Biogas dari kotoran ternak. http: riau.litbang.deptan.go.id. Tanggal Akses 02 Maret 2014.

Hikmat, Harry. 2001. Strategi Pemberdayaan Masyrakat. Bandung, Humaniora Utama Press.

Purba, Jusnita Nuriati. 2008. Pemberdayaan Masyarakat Desa Di Kecamatan Panombeian Panei Kabupaten Simalungun. Universitas Sumatra Utara.

Soebarinoto. 1997. Studi Potensi Hijauan pakan dalam Rangka Pengembangan Sapi Perah di Grati. Buletin Peternakan. $2: 142$.

Sumodiningrat, Gunawan. 1997. Pembangunan Daerah dan Pemberdayaan Masyarakat. Jakarta, Bina Rena Pariwara.

Sunaryo. 2014. Rancang Bangun Reaktor Biogas Untuk Pemanfaatan Limbah Kotoran Ternak Sapi Di Desa Limbangan Kabupaten Banjarnegara. Jurnal PPKM UNSIQ 1(1): 21-30 